price varying from $\$ 1.50$ to $\$ 4$ per week. The Laboratory is open to both ladies and gentlemen.

Cold Spring Harbor is only about an hour's ride from New York, and is in itself a delightful place to spend the summer. It offers opportunities for bathing, boating, and fishing, and a visitor is never at a loss for some pleasant employment. The New York Fish Commission has one of its hatching stations here, and much of interest and profit accrues to the members of the Laboratory frum the study of the specimens in the hatchery. Information as to methods of "fish-hatching and fish-culture is to be had simply for the asking; for the staff at the hatchery are on the best of terms with the members of the biological school, and are willing to accommodate them in every way.

In short, the school at Cold Spring Harbor proposes to offer to all interested in biology a method for spending the summer vacation pleasantly and at the same time profitably. Many are in clined to think the summer vacation of our colleges too long; but it is not so to one who attends such a school, for here he gains both recreation and profit. The Laboratory offers him a chance for acquainting himself with living nature and the living principles of biological science. If he is already an advanced student he is offered chances for special work in the line of topics of his own choosing. If he is a teacher, he can get practical experience with animals and plants, and can make collectionz for his classes; and for the college professor the recreation of the holiday is combined with facilities for research along lines of biological investigation.

Last, but not least, to all is offered opportunity for personal association with educators and original thinkers in lines of science. The school has been successful thus far, and its future promises greater growth and wider influence.

\section{ON SOME HABITS OF AMPHIUMA MEANS.}

\section{BY CHARLES W. HARGITT, SYRACUSE UNIVERSITY.}

'l'HRouar the kindness of Professor H. J. Clements, M.D., of New Orleans, I had sent to me from the Louisiana swamps a halfdozen of the so-called "Congo snakes" early last spring. Tro of them were adults of from twenty to thirty inches in length, the otbers being young ones not exceeding twelve inches from " tip to tip." They were shipped in damp gray " moss," Tillandsia usneides, and with a single exception all came through alive and in good condition.

They were, for want of better quarters, placed in an aquarium in which were a number of fresh-water clams (Unio). At first they were quite sluggish and seemed not at all disposed to be "at home" in their new surroundings. This was especially true of the adult. Gradually, however, the young "Congos" began to show signs of interest and appetite. I found an empty çlam-shell one morning in the aquarium, and further observation soon explained it. No sooner did a clam show signs of declining vitality by an unusual gaping of the shell than it would be seized by one, often indeed by two, of the amphibians, and there was seldom any release till the shell had been relieved of its occupant. The struggle which ensued when two of them would seize a single clam was exciting and amusing in the extreme. Such tugging, writhing, and twisting into perplexing coils one seldom sees, especially among members of this class.

They proved to be exceedingly voracious; and it was but a short time ere they had disposed of some two dozen clams and had shown a remarkable growth, proving the healthfulness of the diet.

This activity, however, pertained only to the young. The adult became more and more sluggish, and it became evident within a fortnight that it would not long endure the conditions. It moreover became quite ugly of disposition, and would bite savagely at anything within reach, even maiming itself. It was consequently consigned to the dissecting-table.

The clams having been disposed of by the others, they were left for a few days without food. My attention was one day attracted to the aquarium by an unusual commotion, and, to my surprise, upon examination, I found that one of the more thrifty had turned cannibal and had half swallowed one of his less vigorous fellows. He was made to disgorge by a sharp squeeze about the thoracic region, and $I$ hoped the thing was at an end. But in less than an hour the same thing was repeated even more savagely and upon the same victim. I immediately removed both from the tank. killing the badly injured one and leaving the otber by itself. Within another day the same thing had been repeated between the two remaining in the aquarian, but was discovered before it had gone so far. They were subsequently fed upon fresh meat from other sources, birds, etc., but did not seem to thrive upon it, finally refusing to take it. They would take earthworms. but showed no disposition to take insect food. One of the number still lives in the same aquarium, and seems fairly at home, so long as fed satisfactorily. It has gone for some time without food with apparently no discomfort. These notes may add something to our knowledge of their probable mode of life. That they are carnivorous is quite certain. At no time did they show any disposition to touch vegetation, though a variety was growing at hand. That under certain circumstances they. with others of their class, will turn cannibal, is also quite certain. I have known the common bull-frog, Rana catesbiana, to devour no less than a half-dozen fair-sized leopard frogs, Rana virescens, within as many days. The same disposition has been noted among the members of other genera. It is less common, indeed rare, between members of the same species and approximately the same size, as was the case under consideration.

\section{NOTES AND NEWS.}

Bulletin 41 of the Purdue University Agricultural Experiment Station contains information of interest and importance concerning wheat as grown in Indiana. The following are some of the points of importance, as given in the Bulletin : 1. Velvet chaff, Michigan amber, and Fultz varieties of wheat have been grown for nine sears on the university farm, and rank in value as named, though Michigan amber surpasses Velvet chaff as a rust-resisting variety. 2. Red Claw son and Junes's winter fife are the two most promising recently introduced varieties. 3. For eight years, six pecks of seed sown per acre hare given the most satisfactory results. 4. In the region of Lafayette, a higher average yield has been secured from wheat sown Sept. 20 over other dates of sowing. 5. Judicious rotations, including grass, have given better return than constant grain-cropping. 6. Heavy applications of manure and fertilizers to a worn soil growing corn and wheat alternately have given paying returns. 7 . The arerage results of all the experiments at this station with fertilizers and manures upon wheat during the past three sears, in full or two-thirds doses, have not been profitable. 8. The use of hot water or copper sulphate failed to destroy the spores of loose smut. 9. Bunt, or stinking-smut, in wheat was successfully destroyed by using hot water or copper sulphate. 10. Early and late harresting of wheat had practically no effect on yield or weight of grain. 11. Yield of grain and straw were considerably reduced by mowing wheat on certain plats in spring to check rankness of growth. 12. In comparing forms of nitrogen for fertilizing the wheat plant, sulphate of ammonia gave rather better yield than nitrate of soda or dried blood. 13. As the plants fertilized with nitrate were slower to mature than the others, these also suffered more from rust than did the others. Persons interested in a more complete account of these wheat experiments, or who wish the publications of the station, can secure free copies of the same by addressing $C . S$. Plumb, director of Experiment Station, Lafayette, Ind.

- The Illustrated American, which has achieved great popularity as the handsomest illustrated weekly published in our country, has been reduced in price from twenty-five to ten cents. This reduction has been brought about by improvements in its engrar. ing and printing establishment, and, it is claimed, will in no way affect its literary and artistic excellence. This change places within the reach of all a most excellent periodical.

- Harrard University is about to publish a reprint of certain important "State Papers and Speeches on the Tariff," by Hami!ton, Gallatin, Webster, and other statesmen, with an introduction by Professor F. W. Taussig. 


\section{Science}

\section{ON SOME HABITS OF AMPHIUMA MEANS}

Charles W. Hargitt

Science ns-20 (502), 159

DOI: 10.1126/science.ns-20.502.159

ARTICLE TOOLS

PERMISSIONS http://science.sciencemag.org/content/ns-20/502/159.1.citation

http://www.sciencemag.org/help/reprints-and-permissions 